\title{
Effect of Vocabulary Building Instruction on Technical School Students' Achievement in Algebraic Word Problems in Benue State, Nigeria
}

\author{
Clement Onwu Iji ${ }^{1}$, Godwin Aôndohemba Fiase ${ }^{2}$, Odihi Adikwu ${ }^{3}$ \\ ${ }^{1}$ Department of Science Education, Federal University of Agriculture, Makurdi, Nigeria \\ ${ }^{2}$ Department of Fitting and Machining Technology, Benue State University Science and Technical College, Makurdi, Nigeria \\ ${ }^{3}$ Department of Educational Foundation and General Studies, Federal University of Agriculture, Makurdi, Nigeria
}

\section{Email address:}

ijiclements07@yahoo.com (C. O. Iji), fiasegodwin@gmail.com (G. A. Fiase), odihiadikwu@gmail.com (O. Adikwu)

\section{To cite this article:}

Clement Onwu Iji, Godwin Aôndohemba Fiase, Odihi Adikwu. Effect of Vocabulary Building Instruction on Technical School Students' Achievement in Algebraic Word Problems in Benue State, Nigeria. Science Journal of Applied Mathematics and Statistics.

Vol. 3, No. 6, 2015, pp. 298-305. doi: 10.11648/j.sjams.20150306.20

\begin{abstract}
Mathematics is used in everyday life, be it social, economic, arts, science or technology. However, empirical evidence shows that students achieve poorly in the subject at School Certificate level especially in the algebraic expression. Research findings have indicated that this low achievement may be attributed to inappropriate pedagogies used by teachers and this necessitated this study. The study made use of a quasi-experimental design of the non-equivalent control group. The sample of 604 part II students was drawn from technical schools in educational zones A and B using multistage sampling technique. Three research questions were raised and three hypotheses were formulated and tested at 0.05 level of significance. The instrumentAWPAT whose reliability was established using Cronbach Alpha to be 0.722 was used for data collection. Data collected was analyzed using mean and standard deviations to answer research questions and analysis of covariance (ANCOVA) to test the hypotheses. The result showed that the Vocabulary Building Instruction method used has enhanced students' achievement significantly. The gap between male and female students on achievement was also minimized. Based on the findings of the study, technical school teachers were recommended to adopt method not only for algebra but other difficult topics in mathematics.
\end{abstract}

Keywords: Vocabulary Building Instruction (VBI), Technical School Students, Algebraic Word Problem, Benue State, Mathematics

\section{Introduction}

The importance of mathematics cannot be overemphasized. This is so because, mathematics is used in everyday life, whether it is social, economic, arts, science or technology (Anyor \& Mbalaha, 2010). Usman (2002) reiterated that it is one of the most important subjects in educating a man. Therefore, mathematics is made a core subject in primary, secondary and technical school system in Nigeria.

It is required that a credit pass in Mathematics at Senior Secondary School Certificate Examinations (SSCE) and National Business and Technical Examination Board (NABTEB) examinations is a necessary requirement for admission into science and science related courses in Nigeria higher institutions but a failure in it, is a major obstacle to admission into the university and even getting a job (Usman, 2002).

In the schools, most mathematics teachers make conscious efforts to teach the subject and gear the process towards students' success on the standardized examinations using mathematics curricula. Also, the students on their part, learn, register and study mathematics with efforts and intention to pass the subject at credit level but it has not achieved the desired successful performance in the subject yet by both secondary and technical school students in Nigeria.

\subsection{Statement of the Problem}

It is particularly disappointing to find that mathematics which algebra is an integral part has remained one of the least successful subjects with gender imbalance in Nigerian schools despite the efforts directed to its success. Series of 
innovative teaching methods to stimulate and improve students' achievement for both internal and external examinations are also advanced by researchers, yet the poor achievement persists. Essentially, this is a worrisome problem giving concern to students, teachers, educational stakeholders, the public and government. It is in the light of the above problems that there is urgent need to explore other alternative teaching methods. Therefore, this study poses the question; could the utilization of VBI stimulate and enhance both the students' interest and mathematics achievement equally on the boys and girls especially in algebraic word problems?

\subsection{Purpose of the Study}

The main purpose of this study was to find out the efficacy of VBI on technical school students' interest, and achievement in algebra. Specifically, the study determined:

1. If the use of VBI would improve technical school students' achievement in algebraic word problems.

2. If the use of VBI would bridge the gap between the male and female technical school students' achievement in algebraic word problems.

3. If interaction effect of gender and VBI on technical school students' achievement in algebraic word problems could be minimized.

\subsection{Research Questions}

The study was guided by the following research questions:

1. What are the mean achievement scores of students taught algebra using VBI and those taught using Conventional Method?

2. What are the mean achievement scores of male and female students taught algebra using VBI?

3. What is the interaction effect of gender and VBI on students' Achievement scores?

\subsection{Research Hypotheses}

The hypotheses formulated the study are tested at 0.05 level of significance.

- There is no significant difference between the mean achievement scores of technical school students taught algebra using VBI and those taught using conventional method.

- There is no significant difference between the mean achievement scores of male and female students taught algebra using VBI.

- There is no significant interaction effect of gender and VBI on students' Achievement scores.

\section{Literature Review}

\subsection{Technical School Students}

Technical school students are set of students who joined vocational and technical schools for learning a trade or skill after junior secondary school in Nigeria. Their educational training is in general education which algebra in mathematics is inclusive to enhance the learning of specific skills in various trades. Their school certificate examinations are Federal Craft, Trade Test and National Business and Technical Examination Board (NABTEB) examinations which lead to award of National Technical Certificate (NTC)/National Business Certificate (NBC). The training enables them after graduation to become artisans, technicians and even engineers for those who can go further in their educational pursuit. It is an educational training that can enable the learner to be self-employed, an employer or can be employed.

\subsection{Vocabulary Building Instruction}

Vocabulary Building Instruction which is the crux of this study refers to a pedagogical strategy programmed in such a manner that a teacher identifies key algebraic words, phrases and statements based on students' needs in the content area during lesson planning (Chard, 2011.). In the lesson execution, the teacher pre-teaches the words using direct and indirect methods to form the students' prior knowledge before the content is taught. It is geared towards providing the students with the opportunity to understand the meanings of certain keywords, phrases or statements and how they are expressed algebraically. Its aim is to nurture the ability and skills in the students to translate verbal, words, phrases or statements into algebraic expressions, formulas or equations. It may work effectively in conjunction with any effective method of teaching.

Chard (2011) asserted that Vocabulary building instruction is useful in removing cognitive barriers that prevent students from grasping new content. Chard further emphasized that students must be actively engage in building background knowledge using key content-specific vocabulary. He reiterated that by preparing students with background information such as vocabulary at the start of the lesson, they are better equipped to put that information to use. The lesson then serves to reinforce new words that stand for concepts as they are learned. The instruction if properly utilized would put meaning to the words that the students encounter in mathematics textbooks and in their assignments. Barton (1998) reiterated that the richer the vocabulary of a learner the better is his capability to learn, understand and perform better than his counterpart who is poorer in the vocabulary of the subject.

Stahl and Fairbanks (1986) emphasized that for teachers to be effective in vocabulary building instruction they must provide more than simple definitions. Stahl and Fairbanks clarified that students need more than just a surface knowledge of the words' definitions. According to them, teaching vocabulary words solely as definitions does not assist students in comprehending the word when found in the text.

The study has procedures of solving word problems and many advantages to both teachers and students. It is student centered and it makes students to use problem-solving procedure. With the approach, students can approach any problem by following this procedure. 
i. Understand the problem. Students are able to read carefully the problem and determine; (a) exactly what they are being asked to find and (b) what information the problem provides. Determine facts pertinent to solve the problem, substitute smaller or simpler numbers to make the problem more understandable, and if possible make sketches to illustrate the problems and label the information given.

ii. Translate the problem to mathematical language. This will generally involve expressing the problem in terms of an algebraic expression or equation. Or determine whether there is a formula that can be used to solve the problem.

iii. Carry out the mathematical calculations necessary to solve the problem.

iv. Check the answer obtained in step iii. Students ask themselves, "Does the answer make sense?" "Is the answer reasonable?" if the answer is not reasonable, recheck your method for solving the problem and your calculations.

v. Make sure you have answered the question. State the answer clearly.

The Vocabulary Building Instruction is compared with the conventional instructional method mostly use in our technical schools.

\subsection{Conventional Method}

The conventional method (CM) which vocabulary building instruction is compared with is also called traditional method and example is lecture or expository method. Some authors like Gbamonja (1991), referred to it as the "talk and chalk" or book method. It is the commonest instructional approaches use by teachers in schools. Teachers teach by copying and solving of mathematical problems without minding whether the students are following or not.

Korah (2001) observed that in a conventional lesson, the teacher teaches the whole class as a unit. He is the master source of knowledge and exercise control over the students. The teacher spends most of his time actually teaching, making the students passive. He does most of the talking. Research studies have shown that average teacher does $70 \%$ talking in the classroom. Much time is spent in narration, description and explanation. The students therefore get the impression that they can learn only when their teacher is present and teaching. Gbamonja (1991) again included the disadvantage of conventional method as, it leads to rote memorization of facts without necessary aiding understanding, since researchers in cognitive psychology supported the view that rote learning is unnecessary, it does not contribute beyond the memorized materials. Another disadvantage of the conventional methods mentioned is that the students easily get bored, frustrated and easily loss interest in the subject, since they are not actively involved in the process. Furthermore, it is said that the conventional method does not take care of the individual differences of the students in terms of learning abilities. The poor achievement and interest of the students in mathematics is also linked to this method. Algebraic vocabulary building instruction is an alternative pedagogical method from conventional method, hence the need to investigate into its effect on technical school students' achievement and interest in algebra.

\subsection{Algebraic Word Problems}

Algebraic Word Problems refers to mathematical/algebraic problems that are stated using words, phrases or statements. They can be verbal or application problems that letters are used to represent the unknown's quantities or values. The words, word phrases and statements are translated into formulas, algebraic expressions and equations that can be evaluated, simplified or solved respectively (Margaret, Stanley, Diana \& Charles, 1998). Before one can translate a problem into an equation (mathematics language), one must understand the meaning of certain words and phrases and how they are expressed algebraically. This is what algebraic vocabulary instruction is out to do.

Also, Allen, Donna, Richard and Prentice (2000) also asserted that algebraic expressions are converted into statements. They further said that often a statement may contain more than one operation.

\subsection{Technical School Students' Interest and Algebraic Word Processes}

The conceptual framework on technical school students' interest and algebraic word process will be better understood by clarifying, interest and algebraic word process for technical school students thus:

Interest has been viewed as emotionally oriented behavioral trait, which determines the students' vim and Vigor in tackling education programs or other activities (Ezewu \& Okoye, 1981). Accordingly Chukwu (2001) stated that effective learning has to do with feelings and values and therefore influences our attitudes and personalities. In viewing effective factors of mathematics learning, Suydan and Weaver (1975) wrote that teachers and other mathematics educators believe that children learn more effectively when they are interested in what they learn and that they will achieve better in mathematics if they like the subject. In other words, interest produces efforts; efforts increases interest and a combination of the two usually result in success. Chukwu (2001) observed that students show little interest in mathematics because of its poor foundation in primary school. She then advised teachers to introduce the subject to the learner in a pleasant and interest manner using interesting and appropriate methods. She emphasized the need to retrain teachers in the use of interesting methods. So, vocabulary building instruction if happened to work well should be the interesting and appropriate method sought after.

Algebraic word processes for technical school students as is contained in NATEB (2007) syllabuses currently in use, include:

- Practical applications to word problem involving basic arithmetic operations with algebraic symbols, insertion and removal of brackets. 
- Application to word problems leading to simple linear equations.

- Application to word problems leading to simultaneous linear equations.

- Application to word problems leading to simple equations involving fractions.

- Application of solution of linear and quadratic equation in practical problems

- Solve a variety of simple equations with practical applications to word problems.

- Formulate problems leading to quadratic functions.

Therefore, technical school students' interest and algebraic word processes refers to the students disposition of wanting to learn and know algebraic problems that are of practical life or are expressed using words. This interest is indicated by students' temperament in the teacher's manner of teaching algebra lessons, their algebra class attendance regularly and punctually, students' participation and voluntary contribution in algebra classes, the manner they solve assignments and homework, practice algebraic exercises make group discussion on word problems and voluntarily forming of mathematics clubs and how they participate in algebra learning activities. The interest behavioural trait is measured using Algebraic Word Problem Interest Scale (AWPIS) instrument. The instrument will be constructed using measurable interest trait variables mentioned above.

\subsection{Technical School Students' Achievement and Algebraic Word Processes}

This refers to scores and grades as outcomes or measure of algebraic word problem learning using instruments like tests, examinations, home works, assignments or projects during or after an instruction. Questions or items in form of assignments, projects, homework, test or examinations are set base on instructional objectives for the students to respond to them. The responses of the students are marked base on predetermined standard called "marking scheme" which enabled the measurement. The ability of a student to recall, comprehend, apply, synthesize, evaluate and judge is measured and scored. In the study, algebraic word problems are used. The extent a student is able to score algebraic word problems is called his achievement. Mathematics standardized tests such as Secondary Schools Certificate Examination (SSCE) and Joint Admission and Matriculation Board (JAMB) examinations consist of word problems also, not only strict computation (Margie, 2010). As pointed out by Stahl and Fairbanks (1986) understanding of mathematics words used in the word problems gives the students a better guide to start and go about solving the problem more logically.

\subsection{Gender and Its Effects on Achievement and Interest}

Sex is concept use to distinguish male and female students according to their biological state of being which the researcher uses interchangeably with gender. It is said to be one of the factors affecting students' socio-cultural and academic phenomena. Halpern (1986) examined sex differences in cognitive ability and concluded that biological factors are significant components to determine sex role differences in cognitive abilities. On the other hand, Majula (2004) reported in his studies that gender (sex) did not influence achievement significantly. The studies conducted on gender as cited above showed that there are inconsistencies on the conclusions reached by the previous researchers. The onus lies on this study therefore to assert if vocabulary building instruction is used, which of the gender would be more favored in terms of achievement and interest in algebraic word problems.

\section{Methodology}

The design used for this study was a quasi- experiment design of non-randomized group, pretest-posttest design of non-equivalent groups. The population of the study was all part II students of technical school in in educational zone A and B of Benue state, Nigeria. The sample for the study consists of only 604 part II students of technical schools in the study area. The instrument used for the study was Algebraic Word Problem Achievement Test (AWPAT) that had 25 multiple choice objective items with four options. The instrument was validated by experts in mathematics education, educational measurement and evaluation. The AWPAT reliability coefficient was found to be 0.722 using Cronbach Alpha. Pre-test was initially administered the students of study before the commencement of treatment. The data collected were analyzed using mean and standard deviation to answer research questions asked while Analysis of Covariance (ANCOVA) was used to test the hypotheses formulated.

\subsection{Answers to Research Questions}

The data collected for each research question is analyzed using mean and standard deviation to answer the research question.

\subsection{Research Question One}

What are the mean achievement scores of students taught algebra using VBI and those taught using Conventional Method?

In order to answer the research question, data were collected relating to the question, analyzed and presented in Table 1.

Table 1. Pretest and Posttest Mean Achievements Scores of Students in VBI and $C M$.

\begin{tabular}{|c|c|c|c|c|}
\hline Achievement & $\begin{array}{l}\text { Group of } \\
\text { respondent }\end{array}$ & Mean & Std. Deviation & $\mathbf{N}$ \\
\hline \multirow{3}{*}{ Pretest scores } & $\begin{array}{l}\text { Experimental } \\
\text { Group }\end{array}$ & 2.50 & 1.17 & 319 \\
\hline & Control Group & 2.55 & 1.18 & 285 \\
\hline & Mean Difference & 0.05 & & \\
\hline \multirow{2}{*}{ Posttest scores } & $\begin{array}{l}\text { Experimental } \\
\text { Group }\end{array}$ & 12.73 & 3.79 & 319 \\
\hline & Control Group & 10.61 & 3.86 & 285 \\
\hline
\end{tabular}


From Table 1, the mean achievement scores in pre-AWPAT of experimental and control are 2.50 and 2.55 while the standard deviations are 1.17 and 1.18 respectively. The mean difference of experimental and control groups at pretest is 0.05. On the other hand, the posttest mean scores for experimental group is 12.73 with standard deviation is 3.79 while control group has the mean 10.61 and standard deviation 3.86. The mean difference at posttest is 2.12 in favor of the experimental group.

Table 2. Pretest and Posttest Mean Achievement of Male and Female Students in VBI.

\begin{tabular}{lllll}
\hline Achievement & Sex of respondent & Mean & Std. Deviation & N \\
\hline Pretest means & Male Students & 2.47 & 1.20 & 235 \\
$\begin{array}{l}\text { Posttest } \\
\text { means }\end{array}$ & Male Students & 12.61 & 3.83 & 235 \\
& Mean Gain & 10.14 & & \\
$\begin{array}{l}\text { Pretest means } \\
\text { Posttest } \\
\text { means }\end{array}$ & Female Students & 2.60 & 1.08 & 84 \\
& Female Students & 13.05 & 3.67 & 84 \\
& Mean Gain & 10.45 & & \\
\hline
\end{tabular}

\subsection{Research Question Two}

What are the mean achievement scores of male and female students taught algebra using VBI?
To answer the research question, data were collected relating to the question. The collected data were analyzed and presented in Table 2 .

From Table 2, the mean scores pretest of male and female students pre-AWPAT are 2.47 and 2.60 while their standard deviations are 1.20 and 1.08 respectively. The mean difference between male and female students in experimental is 0.13 . On the other hand, the mean achievement scores for male and female students in post-AWPAT are 12.61 and 13.05 with their standard deviations is 3.83 and 3.67 respectively. This then means that male students had a mean gain of 10.14 over their mean achievement in pre-AWPAT while the female students gained 10.45 over their mean achievement in pre-AWPAT. This means that both sexes have improved on their achievement scores in algebraic word concepts taught during the period of this study. However, the female students improved more than their male counterparts.

\subsection{Research Question Three}

What is the interaction effect of gender and VBI on students' Achievement scores?

To answer the research question, data were collected relating to the question, analyzed and presented in Table 3.

Table 3. Interaction Effect of Gender and VBI on Students'Achievement Scores.

\begin{tabular}{lllllll}
\hline \multicolumn{2}{l}{ Dependent Variable: } & Posttest scores on achievement of respondent & & & \\
\hline Source & Type III Sum of Squares & df & Mean Square & F & Sig. & Partial Eta Squared \\
\hline Corrected Model & $697.078 \mathrm{a}$ & 3 & 232.359 & 15.881 & .000 & .074 \\
Intercept & 59172.369 & 1 & 59172.369 & 4044.201 & .000 & .871 \\
Group & 468.528 & 1 & 468.528 & 32.022 & .000 & .051 \\
Sex & 19.995 & 1 & 19.995 & 1.367 & .243 & .002 \\
Group * Sex & .000 & 1 & .000 & .000 & .996 & .001 \\
Error & 8778.848 & 600 & 14.631 & & & \\
Total & 92537.000 & 604 & & & & \\
Corrected Total & 9475.925 & 603 & & & & \\
\hline
\end{tabular}

a. $\mathrm{R}$ Squared $=.074$ (Adjusted R Squared $=.069$ ).

From Table 3, reading the row heading Group * Sex and column heading Partial Eta Squared for interaction effect of gender and VBI on students' achievement scores is .001. The calculated percentage of interaction effect $(.001 \times 100=.1 \%)$ $=.1 \%$.

\subsection{Research Hypotheses}

Hypotheses were formulated to test the significance of the findings. The hypotheses were tested at 0.05 level of significance. Since the Statistical Package for Social Sciences (SPSS) is used for this analysis, the 0.05 is compared with Sig. (computer calculated probability for decision taking) value denoted as $\mathrm{P}$. Therefore, if $\mathrm{P}$ is greater than 0.05 the hypothesis will not be rejected (Agber, Ugbagir, Mngutyo \& Amaakaven, 2014).

\subsection{Hypothesis One}

There is no significant difference between the mean achievement scores of technical school students taught algebra using VBI and those taught using conventional method.
To test for the hypothesis, data were collected relating to it, analyzed and presented in Table 4.

Table 4. ANCOVA for the Difference between VBI and CM on Achievement.

\begin{tabular}{lllllll}
\hline Source & $\begin{array}{l}\text { Type III Sum } \\
\text { of Squares }\end{array}$ & df & $\begin{array}{l}\text { Mean } \\
\text { Square }\end{array}$ & F & Sig. \\
\hline $\begin{array}{l}\text { Corrected } \\
\text { Model }\end{array}$ & $7062.274^{\mathrm{a}}$ & 2 & 3531.137 & 879.254 & .000 \\
Intercept & 2351.869 & 1 & 2351.869 & 585.616 & .000 \\
Pre-AWPAT & 6385.607 & 1 & 6385.607 & 1590.018 & .000 \\
Group & 753.857 & 1 & 753.857 & 187.711 & .000 \\
Error & 2413.652 & 601 & 4.016 & & \\
Total & 92537.000 & 604 & & & \\
Corrected & 9475.925 & 603 & & & \\
Total & & & & & \\
\hline
\end{tabular}

In Table 4, reading on row heading Group, it could be seen that $\mathrm{F}=187.711, \mathrm{df}=1, \mathrm{P}=.000<0.05$. This means there is a significant difference in the mean achievement scores of the two groups. Thus, the null hypothesis of no significant difference and therefore rejected. 


\subsection{Hypothesis Two}

Table 5. ANCOVA for Difference between Male and Female Students' Achievement in $V B I$.

\begin{tabular}{|c|c|c|c|c|c|}
\hline \multicolumn{6}{|c|}{ Dependent Variable: Post Achievement } \\
\hline Source & $\begin{array}{l}\text { Type III Sum } \\
\text { of Squares }\end{array}$ & df & $\begin{array}{l}\text { Mean } \\
\text { Square }\end{array}$ & $\mathbf{F}$ & Sig. \\
\hline $\begin{array}{l}\text { Corrected } \\
\text { Model }\end{array}$ & $3260.891^{\mathrm{a}}$ & 2 & 1630.446 & 394.993 & .000 \\
\hline Intercept & 1853.434 & 1 & 1853.434 & 449.014 & .000 \\
\hline PreAch & 3249.190 & 1 & 3249.190 & 787.150 & .000 \\
\hline Sex & .604 & 1 & .604 & .146 & .702 \\
\hline Error & 1304.381 & 316 & 4.128 & & \\
\hline Total & 56238.000 & 319 & & & \\
\hline $\begin{array}{l}\text { Corrected } \\
\text { Total }\end{array}$ & 4565.273 & 318 & & & \\
\hline
\end{tabular}

a. R Squared $=.714$ (Adjusted R Squared $=.712$ ).
There is no significant difference between the mean achievement scores of male and female students taught algebra using VBI.

The test to hypothesis two is presented in Table 5.

In Table 5, reading on row heading Sex, it can be seen that $\mathrm{F}=.146, \mathrm{df}=1, \mathrm{p}=.702>0.05$. This means there is no significant difference in the mean achievement scores of the male and female students in the experimental group. Thus, the null hypothesis of no significant difference is not rejected.

\subsection{Hypothesis Three}

There is no significant interaction effect of gender and VBI on students' Achievement scores.

To test for the hypothesis, data were collected relating to it. The collected data were analyzed and presented in Table 6 .

Table 6. Test of Interaction Effect of Gender and VBI on Students' Achievement Scores.

\begin{tabular}{|c|c|c|c|c|c|c|}
\hline \multicolumn{7}{|c|}{ Dependent Variable: Posttest scores on achievement of respondent } \\
\hline Source & Type III Sum of Squares & df & Mean Square & $\mathbf{F}$ & Sig. & Partial Eta Squared \\
\hline Corrected Model & $697.078 \mathrm{a}$ & 3 & 232.359 & 15.881 & .000 & .074 \\
\hline Intercept & 59172.369 & 1 & 59172.369 & 4044.201 & .000 & .871 \\
\hline Group & 468.528 & 1 & 468.528 & 32.022 & .000 & .051 \\
\hline Sex & 19.995 & 1 & 19.995 & 1.367 & .243 & .002 \\
\hline Group * Sex & .000 & 1 & .000 & .000 & .996 & .001 \\
\hline Error & 8778.848 & 600 & 14.631 & & & \\
\hline $\begin{array}{l}\text { Corrected Total } \\
\text { a. R Squared }=.0\end{array}$ & $\begin{array}{l}9475.925 \\
\text { Adjusted R Squared }=.069 \text { ) }\end{array}$ & 603 & & & & \\
\hline
\end{tabular}

The interaction effect of gender and VBI on students' achievement scores is read across the row heading Group * Sex and column heading Sig. (Group * Sex: Sig = .996). F $=.000$, df $=1$ and Sig. $=.996=$ p. Since $\mathrm{p}>0.05$, the hypothesis is not rejected with the conclusion that the interaction effect of Gender and VBI on students' achievement scores is not statistically significant.

\subsection{Discussion of Findings}

1. Based on the result in Table 1, the findings of the study revealed that vocabulary building instructional (VBI) enhanced achievement of students in algebra especially word problems taught during the period of this study better than conventional teaching method; and the hypothesis was rejected. This finding is in agreement with Ezeugo and Agwagah (2000), Ogwuche and Kurumeh (2011), Orji and Uche (2010), Margie and Susan (2010) who discovered that innovative methods enhanced students achievement in algebra and algebraic word problems.

2. Consequently, based on the results in Table 2, the findings of the study showed that male and female students equally benefited as the difference between them was not significant statistically. This means that the use of VBI had brought about improvement in students' abilities in handling algebraic expressions. Therefore, the use of VBI is encouraging; the null hypothesis of no significant difference is not rejected.
The finding is in agreement with Fennema (2000) who stated that with provision of equality of educational experiences with a suitable instructional method, inequality of students' learning outcomes for male and female students is not expected.

3. Furthermore, the results in Table 5 indicated that the interaction effect of gender and VBI on students' achievement is insignificant. The hypothesis was not rejected with the conclusion that the interaction effect of Gender and VBI on students' achievement scores is not statistically significant. This finding is in agreement with Ajai, Imoko, and O'kwu (2013) who also discovered that interaction effects on achievement due to methods and gender was not significant when they used ProblemBased Learning (PBL) approach on senior secondary school students' achievement in algebra.

\section{Conclusion}

In conclusion, the study takes a detail look at the efficacy of VBI through extensive review of related and relevant literature which revealed some relevant gaps the study eventually filled. The VBI proved to be efficient as students improved upon their achievement in algebra. Most importantly is the friendly nature of VBI which does not discriminate on the basis of gender. This is because the difference between the mean achievement scores of both boys and girls is not statistically significant. 


\section{Recommendations}

The following recommendations were made based on the findings of this study and their implications for education:

i. Ministry of education, state Ministry of science and education and other relevant stakeholders of technical education are encouraged to promote VBI by organizing seminars and workshops for serving teachers in technical schools to acquaint them with the procedures of using VBI.

ii. Curriculum planners and mathematics text books for technical schools writers should be encouraged to include VBI in their books as complementary to other teaching methods.

iii. Technical school administrators and inspectors in collaboration with ministries of science and technical should encourage mathematics teachers to use VBI in their mathematics classrooms.

\section{References}

[1] Abakporo, J. E. (2005). Effective problem solving in mathematics: Challenges and Prospects. The Annual Publication of Mathematics Panel of Science Teachers Association of Nigeria, 8 (1), 19-33.

[2] Agber, T. C., Ugbagir, N. N., Mngutyô, J. N. \& Amaakaven, F. G. (2014). Acquisition of audiovisual materials on the Tiv Tyumbun magic rite by the public libraries in Benue State of Nigeria. LIBRI, 64 (4), 408-419.

[3] Ajai, J. T., Imoko, B. I., \& O'kwu, E. I. (2013). Comparison of the learning effectiveness of problem-based learning (PBL) and conventional method of teaching algebra. Journal of Education and Practice, 4 (1), 131-136.

[4] Allen, R. A., Donna, R. P., Richard, S. and Prentice, H. (2000). Elementary algebra for college students. London: Prentice-Hall International (UK) Ltd.

[5] Anyor, J. W. \& Anyor, M. H. (2007).Attainment of national education goals through mathematics teaching and learning: Innovations in teaching and learning. Makurdi: Adeka Printing and Publishing Company Ltd.

[6] Anyor, J. W. \& Mbalaha, Z. (2010). Repositioning continuous assessment in mathematics and science education for sustainable development in Nigeria. Journal of Educational Innovators, 3 (2), 7-15.

[7] Barton, B. (1998). Ethnomathematics and Philosophy. Zentral blattfür Didaktik der Mathematik, 2 (1), 54-58.

[8] Bassey, S. W., Joshua, M. T. \& Asim, A. E. (2011). Gender differences and mathematics achievement of rural senior secondary students in Cross River State, Nigeria. Proceedings of epi STEME 3.

[9] Chard, D. (2011). Vocabulary strategies for the mathematics classroom. Retrieved from www.eduplace.com//chardhmm05.pdf.

[10] Ezeugo, N. C. \& Agwagha, U. N. V. (2000). Effect of concept mapping on students' achievement in Algebra: Implication for mathematics education in the last century. ABACUS, 25 (1), 1-3.
[11] Fennema, E. (2000). Gender And Mathematics: What Is Known And What Do I Wish Was Known. Retrieved from http://www.iwitts.org/proven-practices/tetaintion-subtopics/women-and-math/329-gender-and-mathematics-whatis-known-and-what-do-i-wish-was-known.pdf.

[12] FME, (2004). National Policy on Education. Yaba: Federal Ministry of Education.

[13] Halliday, M. A. K. (1993). Towards a language-based theory of learning. Linguistics and Education, 5 (3), 93-116.

[14] Harbor-Peters, V. F. (2002), Generating and sustaining interest in Mathematics classroom. In A. O. E. Animalu \& V. F. A. Harbor-Peters (Eds.) Proceedings of the workshop for re-training mathematics teachers at the University of Nigeria Secondary School Nsukka. Enugu: University of Nigeria Press.

[15] Iji, C. O. (2005). Effects of logo and basic programs on students' achievement in junior secondary school geometry. ABACUS, 30 (1), 67-77.

[16] Iji, C. O. (2007). Strategies for effective teaching of mathematics in secondary school: A case of a model project in algebraic processes. Innovations in teaching and learning. Makurdi: Adeka Printing and Publishing Company Ltd.

[17] Kovarik, M. (2012). Building mathematics vocabulary. Retrieved on 13/8/2012 fromwww.cmt.plymouth.ac.uk/.../kovarik.pdf.

[18] Kurumeh, M. S. \& Chiawa, M. A, (2009). Improving students' interest in solving algebraic word problems using aesthetic value approach. Research Journal of Mathematics and Statistics, 1 (2), 59-64.

[19] Kurumeh, M. S. (2006). Effect of Ethnomathematics approach on students' interest in geometry and mensuration. ABACUS, 32 (1), 103-115.

[20] Margie, G. \& Susan, G. (2010). The effects of focused academic vocabulary instruction on underperforming math students. Retrieved from www.ascd.org/ASCD/pdf/building_academic_vocabulary_mat hs_white_paper_web.pdf

[21] Margie, G. \& Susan, G. (2010). The effects of focused academic vocabulary instruction on underperforming math students. Retrieved on 14/10/2012 fromwww.ascd.org/ASCD/pdf/building_academic_vocabulary _maths_white_paper_web.pdf.

[22] NABTEB, (2007). Syllabuses for Miscellaneous Trades Examinations. [DVD].

[23] Obodo, G. C. (2004). Principles and Practice of Mathematics Education in Nigeria. Ibadan: Floxtone Press.

[24] Ogwuche, J. \& Kurumeh, M. S., (2011). Effect of two Problem-solving Models on Junior Secondary School Students' Achievement in Algebra. Journal of Basic and Applied Scientific Research. Journal of Basic Applied Science Research, 1 (5), 333-338.

[25] Orji, A. B. C. \& Uche, A. (2010). Effect of webbing instructional strategy on students' achievement in algebraic word problems. Journal of Research in National Development, 8 (2), 43-42. 
[26] Pallant, J. (2011). SPSS survival manual, a step by step guide to data analysis using SPSS for windows. Berkshire: Open University Press.

[27] The Nation, Thursday august $7^{\text {th }} 2014$ vol. 92931. NABTEB releases May/June results.

[28] UNESCO (2003). Gender and education for all: the leap for equality. Global monitoring report. Retrieved on 12/11/2012 from http://www.unesco/oc.unesco.org/education/etaeport/2003-pdf/chaptr3.pdf.

[29] Usman, K. O. (2002). The need to retrain in-service mathematics teachers for the attainment of the objectives of universal basic education, $A B A C U S, 27$ (1), 37-44. 